\title{
Кафедра аналитической химии МГУ им. М.В. Ломоносова - кузница кадров, оплот фундаментальной науки и генератор новых идей
}

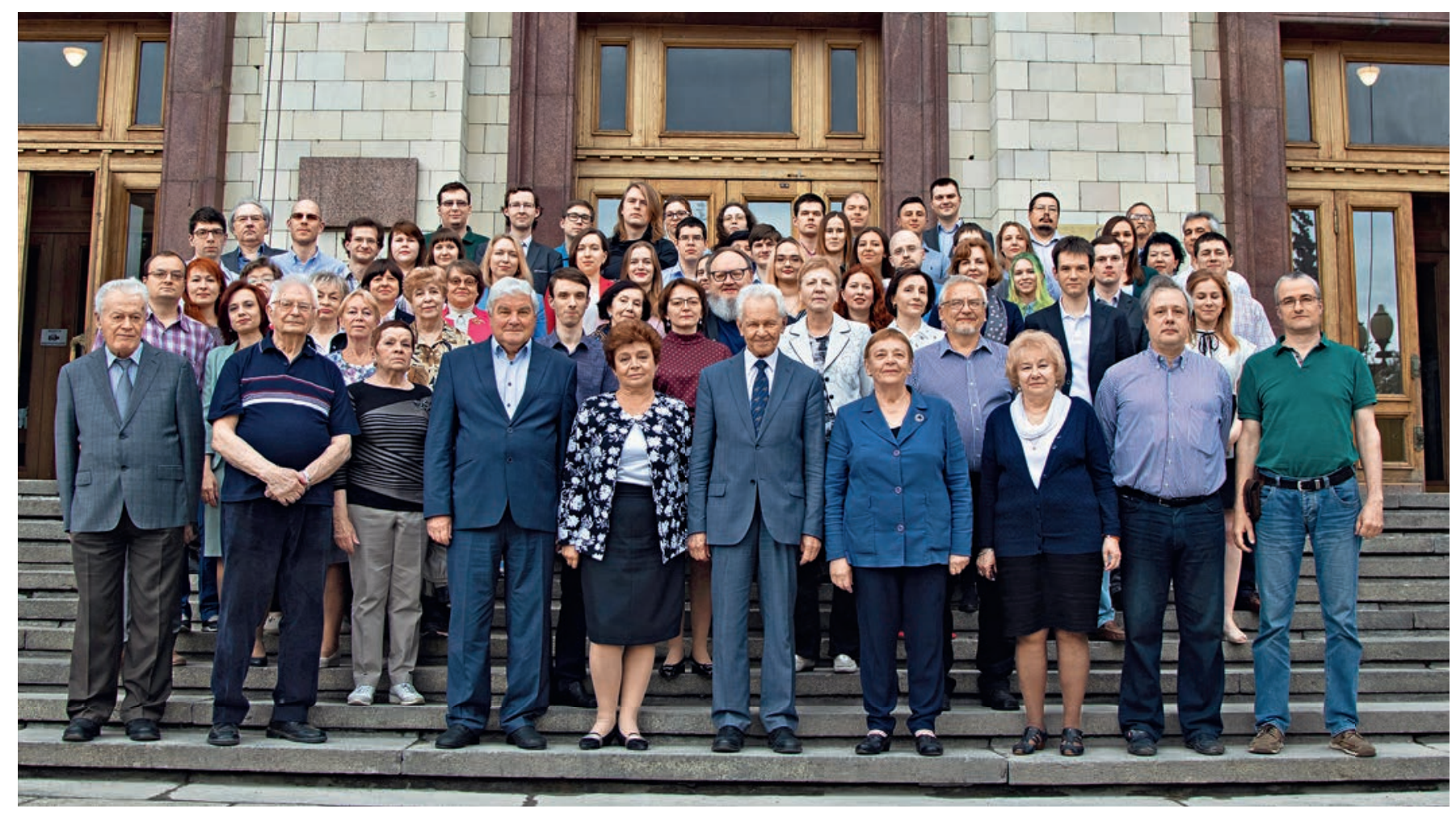

Кафедра аналитической химии - одна из ведущих на химическом факультете Мгу им. М.В.Ломоносова и, пожалуй, самая авторитетная среди учебно-научных подразделений подобного профиля в России. Ровесница химического факультета, кафедра имеет богатую историю, хранит традиции и гордится тем, что многие выдающиеся ученые работали в ее составе. И сегодня уровень профессионализма научного коллектива очень высок, что подтверждается многочисленными публикациями в престижных изданиях и значительными успехами в фундаментальных и прикладных исследованиях. Осенью 2019 года исполняется 90 лет со дня основания кафедры. Круглые даты - время подведения итогов, а нынешняя - особенная, потому что совпала с другим важным событием - сменой заведующего кафедрой. Многолетний руководитель кафедры Юрий Александрович Золотов передал бразды правления Михаилу Алексеевичу Проскурнину. Об учебной и научной работе, успехах и достижениях, проблемах, перспективах и планах на будущее нам рассказали заведующие лабораториями и ведущие сотрудники кафедры. 


\section{Кафедра аналитической химии - стремимся быть первыми рассказывает заведующий кафедрой (на момент публикации снял с себя полномочия) академик РАН, д.х.н., профессор Юрий Александрович золотов}

Кафедра аналитической химии Московского университета в этом году отмечает свое 90-летие, она была создана в 1929 году вместе с химическим факультетом университета в составе пяти химических кафедр. Сегодня кафедра представляет собой довольно мощную структуру, в которой работают 20 докторов наук, практически все остальные сотрудники и преподаватели имеют степени кандидатов наук. Коллектив довольно большой - около 80 сотрудников и 30 аспирантов. Кафедра ведет большой объем преподавательской работы - аналитическую химию изучают в МГу и его филиалах около 1500 человек. Наши преподаватели читают курсы не только на химическом, но и еще на семи факультетах и в двух филиалах - в Баку и Душанбе, а также в некоторых специализированных школах. Много сил задействовано в подготовке специалистов-аналитиков. В год кафедра выпускает от 20 до 30 профессиональных аналитиков, которые востребованы в научных, учебных и производственных организациях. Причем спрос на них наибольший по сравнению с выпускниками других специализаций химического факультета.

На кафедре, естественно, уделяется большое внимание научной работе. В лабораториях представлены практически все современные методы аналитической химии - спектроскопические, масс-спектрометрические, хроматографические, электрохимические и биохимические. Естественно, развивая эти методы, мы стараемся решать и важные прикладные задачи. Перечень этих задач и список приоритетов существенно меняется каждые 10 лет. Например, 30 лет назад в центре внимания были вещества высокой чистоты, геологические объекты, а также металлы и сплавы. Затем на протяжении 15-20 лет в центре внимания были объекты окружающей среды. Сейчас пик интереса сместился в сторону биомедицинских объектов и лекарственных веществ, вод разного типа и пищевых продуктов. Три последние группы - в приоритете анализа. Из экзотических прикладных объектов стоит упомянуть обнаружение взрывчатых веществ с помощью анализа продуктов их распада. Очень интересная и важная тема - обнаружение и количественное определение остатков ракетных топлив, которые попадают в почву и воду от первых ступеней ракет. Большой комплекс работ проведен, в частности, для окрестностей космодрома Байконур.

Стоит упомянуть профессора Игоря Владимировича Плетнева, создающего оригинальные ионные жидкости, которые используются для экстракционного разделения сложных смесей: для смесей химических элементов, и в меньшей степени для органических веществ. Большой цикл работ связан с использованием наночастиц для создания

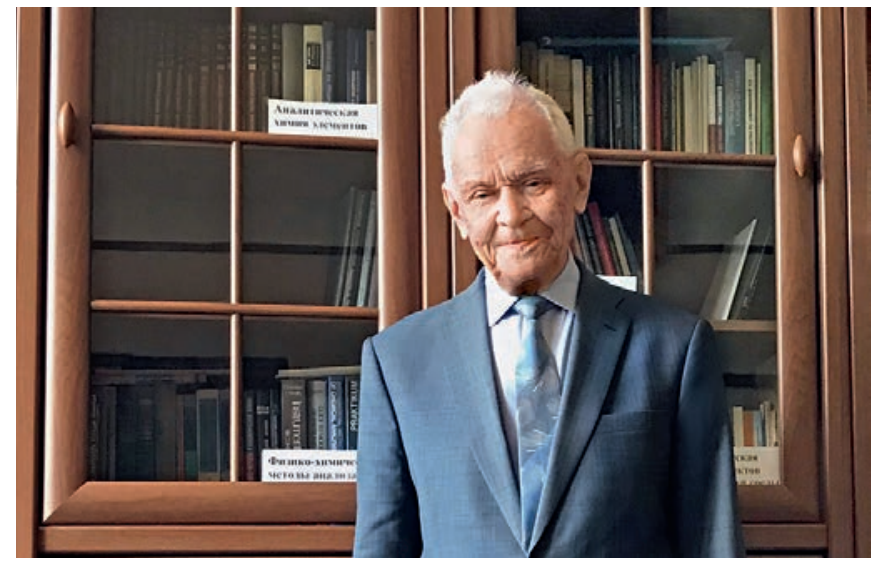

материалов, позволяющих извлекать различные органические вещества из сложных смесей, включая пищевые продукты, эта тема разрабатывается Станиславой Григорьевной Дмитриенко и Владимиром Владимировичем Апяри. Очень любопытна работа по созданию так называемого флуоресцентного глаза, чем занимается Михаил Константинович Беклемишев. Интересные разработки идут в области сочетания концентрирования методом хромадистилляции, разработанным в свое время профессором А. А. Жуховицким, и способа фотохимической ионизации при атмосферном давлении в масс-спектрометрии, предложенного профессором кафедры Игорем Александровичем Ревельским.

Приведу несколько примеров важных прикладных работ, в частности связанных с подтверждением факта применения отравляющих веществ по обнаружению продуктов их распада, которыми являются метилфосфоновые кислоты. Разработаны способы относительно быстрого и селективного обнаружения этих продуктов, которые в объектах окружающей среды сохраняются достаточно долго. Этим занимается группа доктора химических наук Игоря Александровича Родина, работа недавно была отмечена премией имени Митрополита Макария, которую вручал сам Патриарх.

В целом о кафедре с гордостью хочу сказать следующее. Если бы 30-40 лет назад вы спросили у специалистов, какой аналитический центр в стране первый среди равных, они назвали бы Институт геохимии и аналитической химии (ГЕОХИ РАН). Сегодня, я полагаю, многие назовут нашу кафедру. И дело не только в количестве докторов наук, но и во многих других показателях, в том числе по цитируемости. Кафедра активно участвует в подготовке научных конференций, с ее участием проведено три съезда аналитиков России, два международных конгресса по аналитической химии. В течение 30 лет на кафедре подолгу функционировали три 
крупных семинара - по тест-методам, по микрофлюидным системам. А если говорить об учебных достижениях, то это, прежде всего, учебник для классических университетов, создание которого началось в начале 90-х, в 1996 году вышло первое издание, а в 2014 году выпущено шестое. Кроме того, опубликована масса методических и учебных пособий, которыми активно пользуются не только наши студенты.

Есть и примеры международного сотрудничества кафедры, хотя и не того масштаба, который соответствовал бы нашим возможностям. Например, довольно плотно мы контактируем по линии спектроскопических методов анализа с некоторыми центрами в Японии, Словении и других странах. Эти работы ведет Михаил Алексеевич Проскурнин. Сотрудничаем с рядом европейских центров по хроматографии. Чем мы можем гордиться - это плодотворным взаимодействием с приборостроительными организациями, вплоть до организации совместных лабораторий. Такие лаборатории были созданы с фирмами Carlo Erba, BMK "Оптоэлектроника", Agilent Technologies, Shimadzu, что предоставило нам возможность бесплатно получать современное оборудование.

Из знаковых достижений кафедры стоит отметить разработку группой профессора Григория Ильича Цизина способа определения хлора в нефтепродуктах, который стал частью ГОСТа, а недавно на этой основе был выполнен комплекс работ по заказу компании «Транснефть». Эта группа также разработала метод рентгенофлуоресцентного определения большого числа элементов с концентрированием на уникальных фильтрах на основе созданных этой же группой сорбентов. Этот способ используют более 400 лабораторий.

\section{Учебная работа}

рассказывает заместитель заведующего кафедрой по учебной работе, д.х. н., профессор Татьяна Николаевна Шеховцова

Главная задача кафедры со дня ее основания - преподавание общего курса аналитической химии для студентов химического и других (смежных) факультетов, а также подготовка кадров специалистов-аналитиков". Учебный процесс обеспечивает коллектив высококвалифицированных и опытных преподавателей.

Программа основного курса аналитической химии (AX) для химиков остается в течение многих лет практически неизменной: 72 ч - лекции, 64 ч - семинары и 254 ч - практические занятия. Значительное внимание уделено химическим методам анализа, методам обнаружения и разделения, в целом, чуть меньше половины учебного времени. Эти разделы преподают в первом семестре второго курса, он завершается выполнением зачетной задачи - итоговой практической работы, которая заключается в качественном и количественном анализе какого-либо реального объекта: сплава, руды, минерала и т. д. титриметрическим и гравиметрическим методами. Весь второй семестр посвящен изучению фундаментальных основ и практического применения инструментальных методов анализа: спектроскопических, электрохимических, хроматографических. Конечно, в соответствии с современными тенденциями развития АХ объем инструментальных методов следовало бы существенно увеличить, однако это потребует значительных затрат на приобретение нового оборудования, к чему университет не готов. Студенты выполняют курсовую работу по АХ в одной из научных лабораторий кафедры, результаты оформляют по образцу дипломных работ и, подготовив презентации, защищают их устно

Подробнее о преподавании аналитической химии в МГУ см. в журнале "АНАЛИТИКА", 2018, т. 8, № 5, с. 438-443. на общем семинаре группы в присутствии комиссии преподавателей.

Отмечу, что объективность оценки знаний студентов обеспечивается благодаря модульнорейтинговой системе, введенной на кафедре более 25 лет назад. За выполнение каждой позиции учебного плана выставляются баллы,

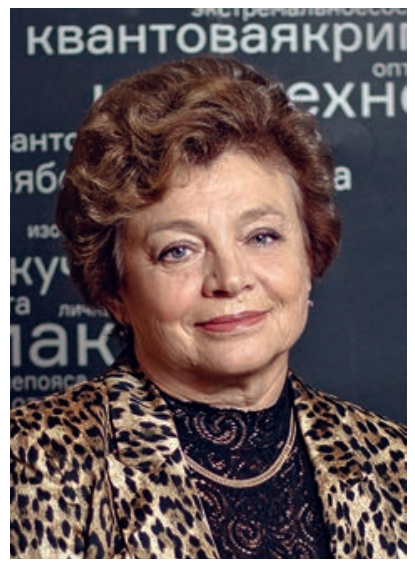
которые суммируются в течение семестра и влияют на итоговую оценку.

Распределение студентов по кафедрам на химическом факультете проходит на третьем курсе, а специализация начинается на четвертом. Важно подчеркнуть, что из-за продления на год (до шести лет) срока обучения специалистов-химиков в МГУ значительно возросло количество часов, отводимых на преподавание специальных дисциплин. По новому учебному плану вариативная профессиональная часть составляет почти 40 зачетных единиц (з.е.)

Благодаря увеличению объема аудиторных часов, к традиционным курсам, таким как современные хроматографические, спектроскопические, электрохимические методы анализа; методы разделения и концентрирования; способы пробоотбора и пробоподготовки; кинетические, биохимические и биологические методы анализа; основы химической

\footnotetext{
: Одна зачетная единица составляет 36 академических часов. - Прим. ред
} 
метрологии и хемометрики; анализ реальных объектов; аналитическая служба и аналитический контроль, - в последние годы добавлены новые:

- масс-спектрометрические методы анализа;

- проточные методы анализа;

- хиральная хроматография и капиллярный электрофорез;

- различные аспекты применения в химическом анализе ионных жидкостей;

- внелабораторный химический анализ.

Наряду с глубоким изучением теоретических основ студенты приобретают экспериментальные навыки в спецпрактикуме "Аналитическая химия" (9 з.е.) по спектроскопическим, масс-спектрометрическим, электрохимическим и хроматографическим методам анализа. Спецпрактикумы кафедры оснащены современным, в основном импортным оборудованием.

В десятом семестре введен новый экспериментальный курс "Современные проблемы химии" на английском языке (4 з.е.) с итоговым зачетом также на английском языке. В рамках этого курса с лекциями часто выступают иностранные ученые. Опыт интересный, но о его эффективности судить пока рано.

Нововведение последних лет - выпускной государственный экзамен по химии в конце шестого курса, на котором выпускник должен продемонстрировать знания фундаментальных основ своего направления специализации (критерий "знание») и навыки проведения эксперимента для получения конкретного результата (критерий "умение»). Принимает экзамен комиссия из преподавателей кафедры и представителей учреждений и предприятий - потенциальных работодателей. Через две недели после госэкзамена проходит защита дипломных работ в присутствии той же комиссии.

На кафедре ежегодно обучаются около 30 аспирантов, которые в течение четырех лет (по новому положению) должны прослушать лекции и сдать зачеты или экзамены по специальным курсам по согласованию с руководителем. Ведущие специалисты кафедры читают лекции по дисциплинам:

- избранные главы хемометрики (многомерные данные в химическом анализе);

- современные методы анализа поверхности, тонких пленок и низкоразмерных структур;

- аналитическая лазерная спектроскопия;

- актуальные проблемы современной аналитической химии.

Отмечу как несомненно позитивное введение в учебные планы подготовки специалистов и аспирантов таких педагогических дисциплин, как педагогика, психология, методология и практика преподавания химии. В результате выпускники получают диплом, в котором указано, что они являются не только "химиками-исследователями", но

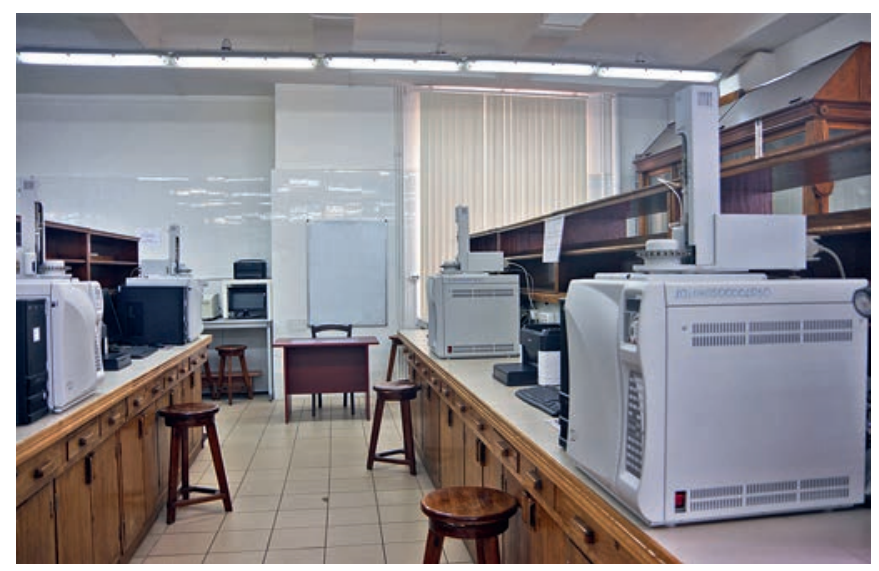

Лабораторный практикум кафедры

и "преподавателями химии", что значительно расширяет возможности их трудоустройства.

По окончании аспирантуры выпускники сдают государственный экзамен, который проходит в два этапа. На первом - аспиранты должны защитить в виде доклада с презентацией представленный заранее в электронном виде для рецензирования специалистами в области педагогики какой-либо продукт - методическую разработку, планконспект семинара, лекции, новую разработанную задачу для практикума и т. п. Второй этап состоит в представлении научного доклада по исследовательской работе за все время обучения в аспирантуре. По результатам этого этапа комиссия делает вывод о готовности аспиранта к защите диссертации. После успешной сдачи экзамена аспирант получает диплом об окончании аспирантуры.

Несколько лет назад кафедра аналитической химии активно включилась в работу в системе дополнительного образования для сотрудников различных предприятий, фирм, госучреждений, преподавателей высшей школы. После дистанционного прослушивания лекций, в некоторых курсах (например, по хроматографии), дополняемых

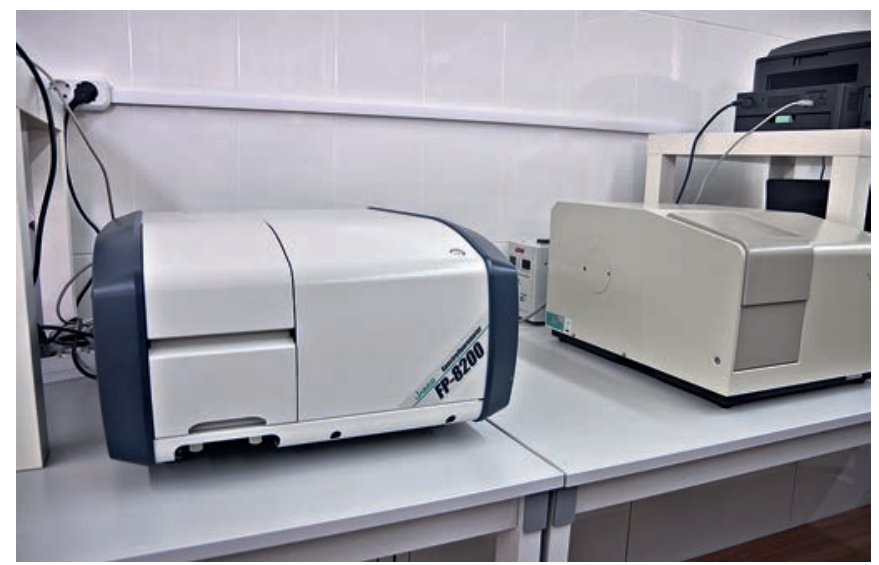

Учебный спектрофлуориметр 
практическими работами непосредственно в лабораториях кафедры, слушатели сдают письменные или устные экзамены, получают сертификат МГУ о получении дополнительного образования по определенной программе. Приобретенный опыт показал эффективность такого дистанционного обучения, и, следуя пожеланиям заказчиков, кафедра подготовила несколько наиболее востребованных дистанционных лекционных курсов: "Современные методы химического анализа", "Газовая хроматография", "Хроматография и капиллярный электрофорез", "Молекулярная спектроскопия", "Атомная спектроскопия". Курсы читаются по мере того, как формируются группы слушателей.

\section{Научные лаборатории}

В структуру кафедры входят шесть научных лабораторий: концентрирования (зав. Ю.А. Золотов), хроматографии (зав. О.А. Шпигун), спектроскопических методов анализа (зав. М.А. Проскурнин), масс-спектрометрии (и.о. зав. И.А. Родин), электрохимических методов анализа (зав. А. А. Карякин), биоаналитических методов и оптических сенсорных систем (зав. Т.Н. Шеховцова)

\section{ЛАБОРАТОРИЯ СПЕКТРОСКОПИЧЕСКИХ МЕТОДОВ АНАЛИЗА}

Рассказывает заведующий лабораторией д.х. н., профессор Михаил Алексеевич Проскурнин, в настоящее время исполняющий обязанности заведующего кафедрой аналитической химии

Наша лаборатория - одна из "лабораторий-основателей" кафедры и одна из самых больших, поскольку спектральные методы были, есть и будут ключевыми для аналитической науки. Традиционно, из-за большого разнообразия спектральных методов анализа, работа в лаборатории ведется в нескольких направлениях. Мы проводим как фундаментальные, так и прикладные исследования, при этом не ограничивающиеся только аналитической химией, а связанные с физической химией, созданием новых материалов, с фундаментальными исследованиями в области наук о Земле, в области биологии и медицины.

Уже более 30 лет мы работаем в области фототермической спектроскопии (руководитель группы М. А. Проскурнин). Фототермическими называются оптические явления, вызванные поглощенным излучением. Например, миражи в пустыне и "зеркальный" асфальт в жаркий день можно наблюдать благодаря этим явлениям. Фототермическая спектроскопия - это группа методов, основанных на регистрации изменений показателя преломления, вызванных поглощением электромагнитного излучения. Сигнал прямо пропорционален оптической плотности и, следовательно, концентрации поглощающего компонента и коэффициенту светопоглощения. Фототермическая спектроскопия обеспечивает рост чувствительности по сравнению со спектрофотометрией на один-два и более порядков и дает возможность проводить следовый анализ вплоть до отдельных нефлуоресцирующих молекул и расчеты теплофизических параметров сложных сред, исследовать живые системы in vivo. Помимо аналитической и физической химии, области применения фототермической спектроскопии весьма широки - от лазерной физики, теплофизики, био- и нанофотоники до неразрушающего контроля, материаловедения, лазерной медицины и тераностики. В этой области мы активно сотрудничаем с рядом ведущих университетов и научных центров США,

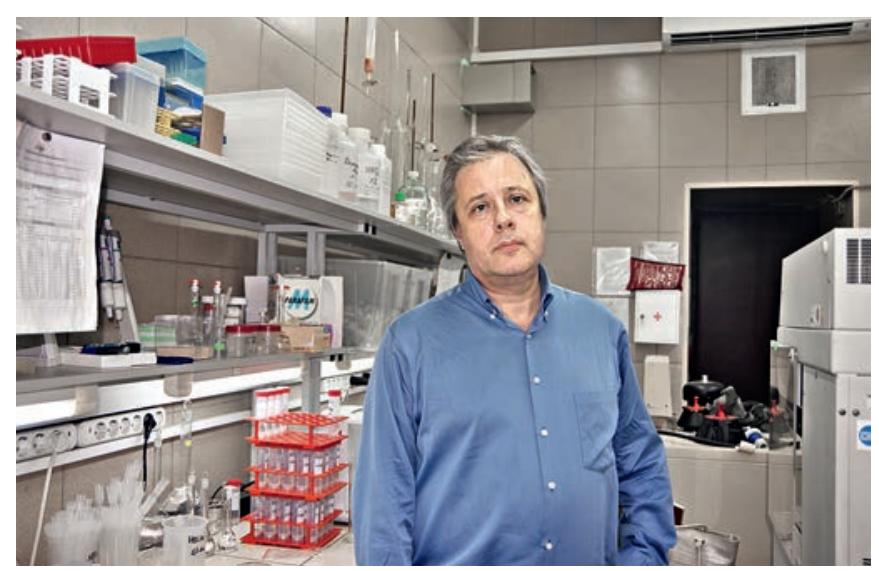

Канады, Японии, Италии, Франции, Германии, Словении а также с лабораториями Физического факультета МГу (д. ф.-м. н. проф. Александр Алексеевич Карабутов) и НИту МИСиС (к.х.н. доц. Вера Александровна Филичкина).

В области ИК-спектроскопии работа в лаборатории (к.х.н. С.н.с. Дмитрий Сергеевич Волков) направлена на использование ИК-спектроскопии и ее современных возможностей (НПВО-ИК-спектроскопии, оптоакустической ИК-спектроскопии) в количественном химическом анализе сложных объектов. Разрабатываются комплексные методы для определения или оценки аналитических и физикохимических характеристик всех слоев сложного объекта: ядра частицы, поверхностных слоев и функциональных групп в них, микропримесного состава, размера и степени агрегации наноразмерных материалов. Такое исследование проведено для наноалмазов. Сегодня проводится изучение фракционного состава и других сложных объектов - почвенных частиц, инженерных наночастиц разных классов. Совместно с кафедрой физической химии (д.х.н. проф. Михаил Валерьевич Коробов) изучаются химические 
и физические свойства водных дисперсий углеродных частиц - оксида графена, фуллеренов (м.н.с. к.х. н. Иван Владимирович Михеев). Отдельно стоит упомянуть совместную работу, с кафедрой медицинской химии (д.х.н. проф. Ирина Васильевна Перминова) и Почвенным институтом РАН им. В. В. Докучаева (к. б.н. Ольга Борисовна Рогова) по изучению гуминовых веществ и органического вещества почв.

Д.ф.-м.н. проф. Михаил Александрович Большов и к. х. н. доц. Ирина Филипповна Серегина и их сотрудники к.х.н. А. С. Дубенский и к.х. н. С. Ю. Ланская используют в работе ИСП-МС, один из самых чувствительных методов элементного анализа. Основные задачи - разработка эффективных методик пробоподготовки для рудных, минеральных и биологических образцов элементов платиновой группы. Как и в других исследованиях, очень многие задачи, идущие "от объекта", требуют привлечения и других методов анализа, оптической и рентгеновской спектроскопии.

Спектрофлуориметрия была на кафедре важным инструментом исследований, сейчас мы стараемся развить эту работу на новом современном уровне - закупаем оборудование, создаем практически значимые методики для целевого использования в почвоведении, анализе нефтепродуктов и т.д.

Исследованиями в области рентгенофлуоресцентного анализа занимается группа студентов и аспирантов под руководством К.х.н. доц. Кирилла Владимировича Осколка и к.х.н. доц. Оксаны Викторовны Моногаровой. Разрабатываются методы обработки сигнала, способы пробоподготовки, включая жидкостную микроэкстракцию и оригинальные методы. В последнее время круг задач, решаемых при помощи рентгенофлуоресцентного анализа, существенно расширяется за счет новых приборов, поступающих на химический факультет по Программе Развития МГУ им. М. В. Ломоносова - микрорентгенофлуоресцентного спектрометра, НПВО-РФА.

Работа К. В. Осколка и О. В. Моногаровой также связана с разработкой простых, но эффективных решений в области оптической спектроскопии - мультисенсорной цифровой цветометрии. Активно развиваются методы обработки спектральной информации, в области оптической спектроскопии (Дмитрий Сергеевич Волков), рентгеновской спектроскопии (к.х.н. Андрей Владимирович Гармай), спектральной информации в широком смысле этого слова (к.х.н. доц. Андрей Викторович Гармаш). Работа в области цифровой цветометрии, опубликованная в журнале Talanta, вызвала даже некоторый резонанс в СМИ. Как сообщило агентство "Москва": "Сотрудники кафедры анапитической химии на основе бытовых пазерных указок с фокусирующими линзами создали прототип предельно простого и дешевого молекулярного оптического анализатора, внешне напоминающего меч Джедая из киноэпопеи „Звездные войны“". Анализатор можно использовать для определения состава различных жидкофазных объектов.

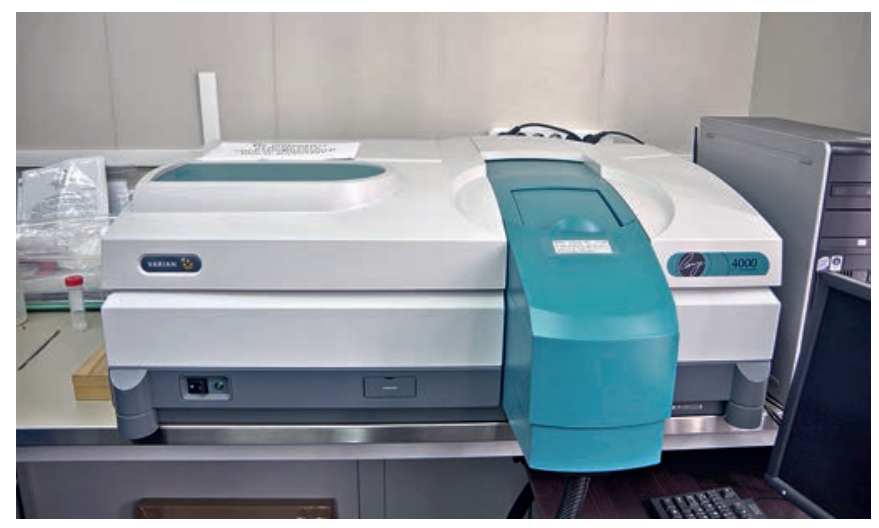

Cneкmрофотометр Varian Cary 4000

В практической работе мы используем современные методы аналитической спектроскопии: масс-спектрометрию с индуктивно связанной плазмой, атомно-абсорбционную спектроскопию, атомно-эмиссионную спектроскопию с индуктивно связанной плазмой, спектрофотометрию, спектрофлуориметрию, оптическую и ИК-микроскопию, рентгеновскую флуоресцентную спектроскопию. Сотрудники кафедры выполняют многие практические задачи, в частности в области анализа природного сырья, промышленных объектов, продуктов новых технологий (к.х.н. доц. Дарья Геннадьевна Филатова, к.х. н. доц. Андрей Геннадьевич Борзенко, Павел Юрьевич Шаранов). Мы разрабатываем сертифицированные методики для целого ряда методов. Многие решения проистекают из совместной работы с другими коллективами.

Мы всемерно стремимся развивать сотрудничество как с коллегами из других факультетов Мгу (физический, почвоведения), так и с научными организациями нашей страны (НИТУ МИСиС, Почвенный институт им. В.В. Докучаева, МГту им. Н. Э. Баумана, ИОНХ им. Н. С. Курнакова, МГНЦ им. академика Н. П. Бочкова, ГЕОХИ им. В. И. Вернадского). Почти всегда это мультидисциплинарные исследования, связанные с биологией, медициной, материаловедением и другими науками. Развитие новых современных инструментальных методов аналитической химии требует очень больших вложений, поэтому не все удается сделать в одиночку в сегодняшних реалиях. Но за счет совместных усилий и научной коллаборации мы стремимся максимально использовать имеющийся потенциал отечественной научной школы.

Кроме того, очень плодотворно сотрудничество с компаниями-производителями аналитического оборудования и их российскими представителями. Важно здесь, на мой взгляд, именно научное и во всех смыслах партнерское взаимодействие специалистов фирм и сотрудников лаборатории, да и кафедры в целом, а также привлечение студентов и аспирантов к такой совместной работе. Отмечу компанию Bruker, прежде всего отделения Bruker Optics 


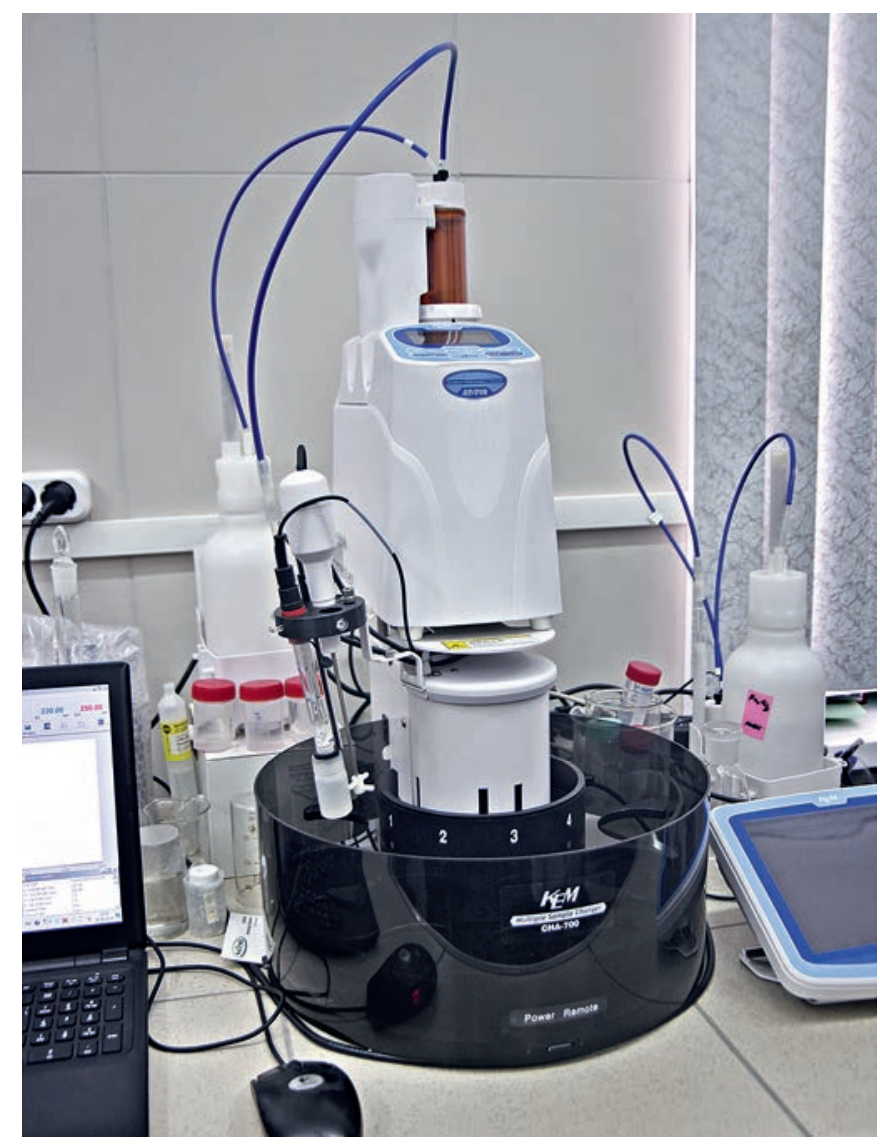

Автоматический mumpamop AT-710 (Kyoto Electronic Manufacturing)

(оборудование для ИК-спектроскопии) и Bruker Nano (оборудование для рентгенофлуоресцентного анализа).

Также мы давно взаимодействуем с российской компанией “СокТрейд”, благодаря двум обстоятельствам. С одной стороны, многие сотрудники компании являются выпускниками химического факультета. С другой стороны, генеральный директор Евгений Анатольевич Новиков полагает, что на отечественном рынке должны быть представлены не только крупные корпорации, поэтому “СокТрейд" предлагает очень широкий спектр интересного аналитического оборудования. Мы применяем различное оборудование, предоставленное компанией, например автоматический титратор. Планируем совместную работу по развитию микрофлюидных технологий.

Хотелось бы отметить весьма продуктивное сотрудничество в рамках Партнерской лаборатории Agilent, и выразить благодарность компании Agilent Technologies и Константину Юрьевичу Евдокимову, директору отдела решений в области химического анализа ее российского представительства. Наше сотрудничество включало работы по спектрофотометрии, спектрофлуориметрии, атомно-эмиссионной спектроскопии с индуктивно-связанной и микроволновой плазмой.

В заключение совсем кратко о себе. Я - химик в третьем поколении. Мой дед, профессор, д.х.н. Михаил Алексеевич Проскурнин - ученик академика А. Н. Фрумкина и один из пионеров советской радиационной химии, работал в МИТХТ и НИФХИ им. Л. Я. Карпова. Родители -химики-технологи специализировались в области органического синтеза, оба кандидаты химических наук. Меня всегда интересовала физика, и в работе я стремился развивать в химико-аналитическом аспекте сложные физические методы, поэтому, будучи еще студентом, выбрал в качестве своего основного научного направления упомянутую выше фототермическую спектроскопию. Знания и мышление химика позволили мне, как и другим моим коллегам, внести в физические методы аналитическую методологию и структуризацию исследований. Как показывает практика, междисциплинарное сотрудничество крайне важно для эффективной работы, и когда физики с биологами проводят исследования на стыке наук, им крайне нужны химики, химики-аналитики из-за широты их мышления. Многие выпускники нашей лаборатории работают в различных исследовательских группах, как в нашей стране, так и в Японии, США, Швеции, Германии и Франции. Химики-аналитики с нашим образованием оказались востребованы и в мультидисциплинарных исследованиях, даже в физике, биологии и медицине.

\section{ЛАБОРАТОРИЯ КОНЦЕНТРИРОВАНИЯ}

Рассказывает главный научный сотрудник лаборатории, руководитель одной из четырех научных групп д. х. н., профессор Григорий Ильич Цизин

В каждой научной группе нашей лаборатории есть направления, интересные с точки зрения развития науки, но они не всегда близки к решению практических задач, и, наоборот, есть практические разработки, в которых научная составляющая невысока. На примере нашей группы я расскажу о некоторых направлениях обоих типов. Например, мы предложили использовать воду в субкритическом состоянии при температурах 150-200 들 давлением, которую легко получить в типовом жидкостном хроматографе, в проточных сорбционно-ВЭЖХ-системах анализа для замены водно-органических элюентов. Водный концентрат после выхода из концентрирующей колонки можно легко и быстро охладить и подать в обычную хроматографическую колонку, где произойдет резкое фокусирование веществ-аналитов. Такая система с "двойным" концентрированием обеспечивает сужение хроматографических пиков и позволяет анализировать более сложные смеси веществ, чем при использовании традиционных подходов. 
Это пример научной разработки на перспективу, которая еще не скоро получит активное практические применение. Для внедрения таких систем необходимо в первую очередь выпустить соответствующее типовое оборудование, а это процесс не быстрый.

Приведу обратный пример. В 2006-2007 годах нас привлекли в качестве одного из коллективов, принимавших участие в межлабораторных испытаниях очень простого метода - рентгенофлуоресцентного определения хлорорганических соединений в нефти. Научные аспекты этого направления никак нельзя признать весомыми - по сути, требуют установления лишь метрологические аспекты такого определения. У нас даже нет ни одной научной публикации на эту тему. Однако, указанная проблема внезапно стала весьма актуальной в связи с известными событиями вокруг поставок нефти в Белоруссию и Европу. В результате, учитывая предыдущий опыт, нашу группу привлекли к разработке нового ГОСТа, также к нам обращаются крупные нефтяные фирмы и даже представители силовых структур. Сейчас встал вопрос о создании полностью автоматизированных комплексов для анализа нефти, что представляет весьма сложную задачу.

Третий пример, который и сочетает развитие науки, и связан с решением важной практической задачи. Несколько лет назад, изучая возможности использования субкритической воды в системах концентрирования, мы столкнулись с серьезной проблемой - большинство сорбентов не выдерживали эту агрессивную среду. В результате исследований мы пришли к тому, что единственным сорбентом, отвечающим всем требованиям, является пористый графитированный углерод (например, гиперкарб). Однако позже, уже не в рамках исследований применения субкритической воды, мы выяснили, что уникальные свойства гиперкарба позволяют эффективно разделять и определять продукты деградации боевых фосфорорганических отравляющих веществ, например - алкилфосфоновых кислот и других. Эти вещества, конечно, определяли и до нас, но с помощью гиперкарба удалось разработать экспрессные и чувствительные методики. За эти работы сотруднику нашей группы М. А. Статкусу присуждена премия имени метрополита Макария.

Таким образом, из приведенных примеров видно, что в рамках одной научной группы можно сочетать развитие

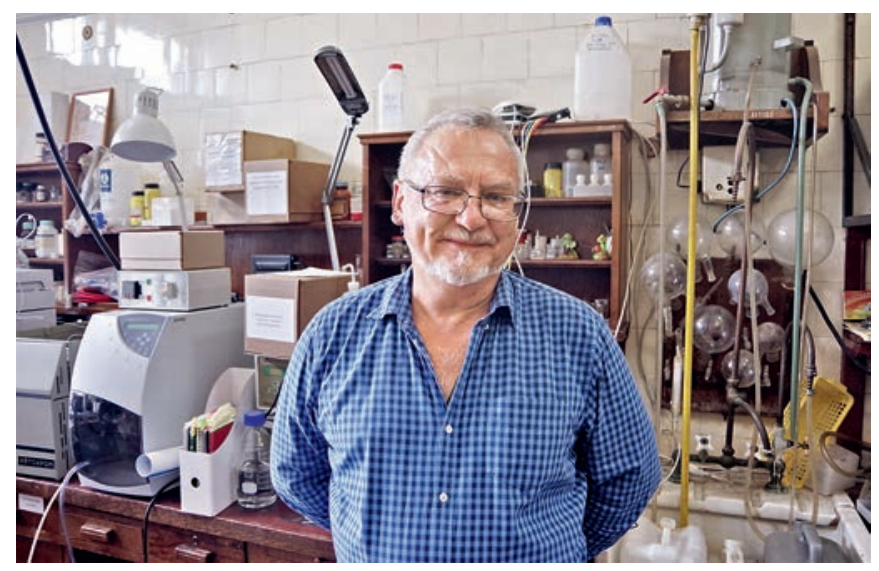

научных направлений с решением актуальных практических задач.

Приведу яркий пример работы нашей группы, выполненной ранее и нашедшей широкое практическое применение: мы разработали и синтезировали сорбенты с конформационно подвижными группами, которые извлекают тяжелые металлы гораздо эффективнее, чем другие сорбенты. В результате предложены тонкослойные фильтрысорбенты и микроколонки для проточных систем анализа. Эти сорбенты сегодня используют в сотнях организаций для контроля окружающей среды и пищевых продуктов. За этой разработкой стояли годы кропотливой научной работы. За широкое внедрение этих разработок мне присуждена премия РАН им. В. А. Коптюга.

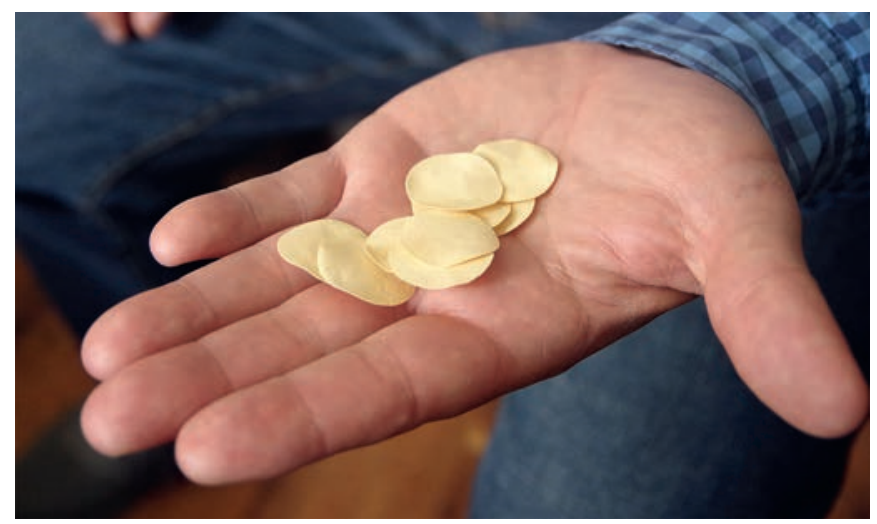

ДЭТАТА-фильтры для концентрирования тяжелых металпов
Рассказывает старший научный сотрудник

д. х. н. Владимир Владимирович Апяри

Наночастицы стали новой вехой в аналитической химии. Перспективы их применения очень широки. Благодаря высокой удельной поверхности и особым свойствам вещества в наноразмерном состоянии, наночастицы используют для разработки аналитических реагентов, сорбентов и сенсорных систем нового поколения. Принципы функционирования подобных систем отличаются от классических, что в итоге приводит к увеличению чувствительности методик, изменению их селективности, расширению аналитических возможностей. 


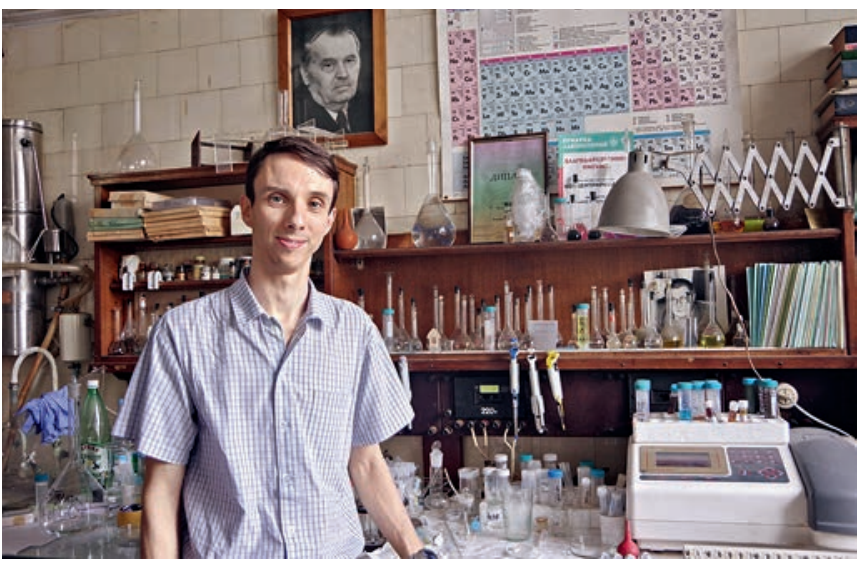

Одним из интенсивно развивающихся сегодня направлений наноаналитики является разработка спектрофотометрических и цветометрических реагентов с использованием наночастиц и материалов на их основе. В рамках этого направления мы получили и изучили наночастицы разной формы. Это сферические наночастицы и наностержни золота, сферические и треугольные наночастицы серебра. Их можно использовать для простого и быстрого обнаружения веществ: лекарственных, биологически активных препаратов, антибиотиков, средств, которые используют для дезинфекции. Например, мы разработали способ определения дезинфектанта полигексаметиленгуанидин гидрохлорида (ПгМГ), который предлагают, в частности, для бассейнов. Определение возможно за счет того, что наночастицы резко меняют свой цвет в присутствии даже малых количеств определяемого компонента. Можно легко провести экспресстест - визуально сравнить со цветовой шкалой и понять,

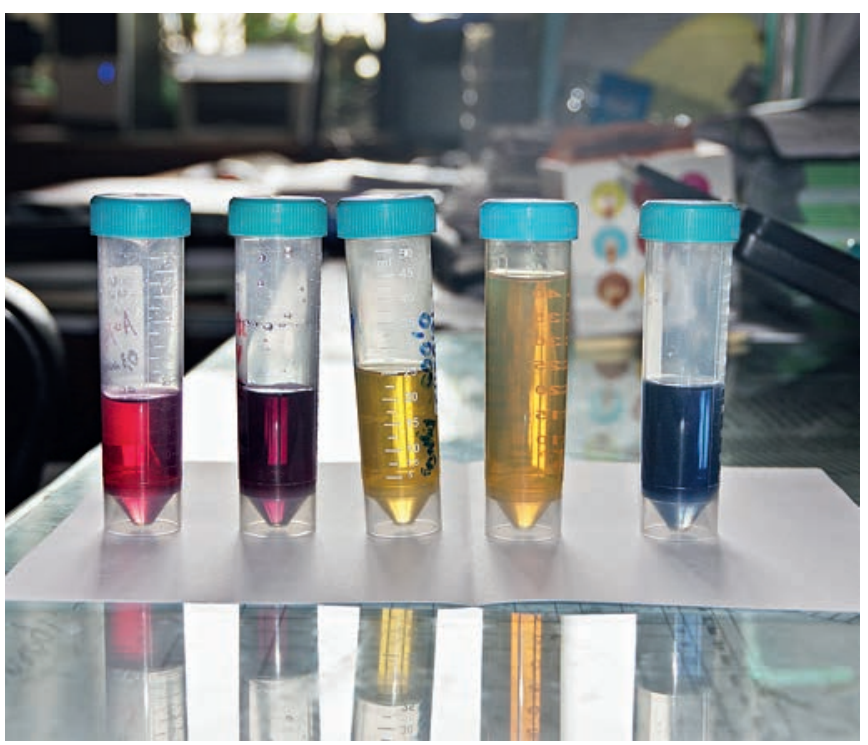

Колюоидные растворы наночастиц золота и серебра различных размеров и формы что, например, в воде бассейна присутствует упомянутый дезинфектант. И если да, то превышает его содержание норму или нет.

Спектральные характеристики наночастиц можно варьировать. Например, коллоидные растворы сферических наночастиц серебра имеют желтый цвет, а треугольных нанопластинок того же металла - синий. Можно в широких диапазонах менять свойства наночастиц и, следовательно, - характеристики соответствующих методик - чувствительность, селективность.

Помимо визуальной регистрации аналитического сигнала, конечно, можно использовать соответствующие приборы - фотометры. Они сейчас доступны многим, имеются почти в любой лаборатории и стоят недорого. В сочетании с такими приборами методики с применением наночастиц могут быть реализованы с высокой чувствительностью и точностью, а кроме того они экономически оправданы.

Другое важное направление наших исследований магнитные сорбенты, которые мы синтезируем с применением магнитных наночастиц. Главная особенность этих сорбентов состоит в том, что их легко извлечь из раствора с помощью постоянного магнита. Классические сорбенты нужно отделять фильтрованием, центрифугированием, это сложные и длительные процессы. При работе с магнитными сорбентами достаточно поднести к пробирке с анализируемым раствором сильный магнит, и весь сорбент скапливается в зоне действия магнита. Далее раствор нужно просто слить, добавить подходящий растворитель и элюировать вещества с сорбента. Затем сорбент тем же способом легко отделяется от концентрата.

Мы синтезируем сорбенты на основе известных матриц, например сверхсшитого полистирола, и магнитных наночастиц. Этот новый материал можно использовать для выделения и концентрирования сульфаниламидов, тетрациклиновых антибиотиков и многих других веществ.

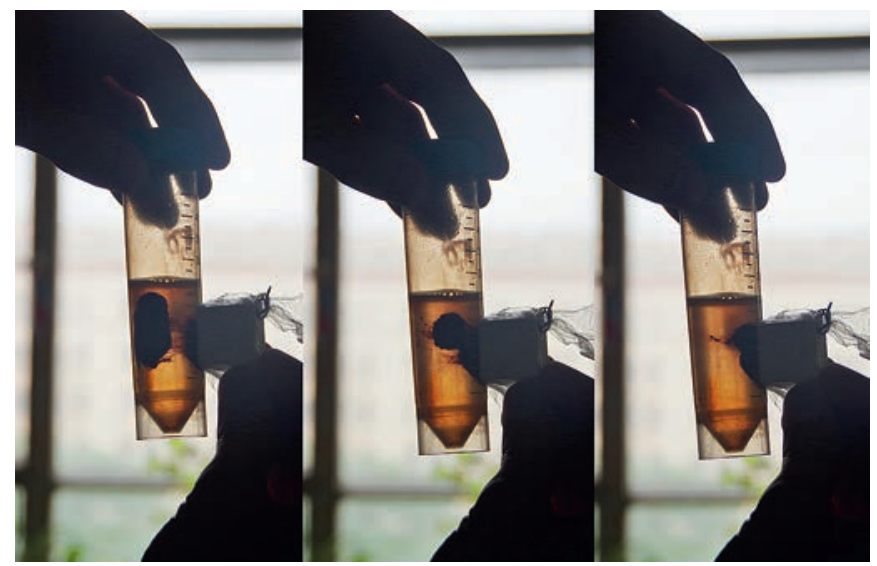

Смещение магнитного сорбента под действием поля постоянного магнита 


\section{ЛАБОРАТОРИЯ ХРОМАТОГРАФИИ}

Рассказывает заведующий пабораторией член-корр. РАН, д. х. н., профессор Олег Алексеевич Шпигун

Лаборатория хроматографии в прошлом году отметила 30-летие своей деятельности. До 1988 года работала научная группа в составе лаборатории концентрирования. Если бы в 70-е годы мне сказали, что я буду заниматься хроматографией, ни за что бы не поверил.

Начинали мы с ионной хроматографии - 30 лет назад это был самый новомодный метод, но впоследствии интересы переместились в область жидкостной хроматографии. Сегодня в составе лаборатории 17 сотрудников и 16 аспирантов и столько же дипломников. Мы не берем в год больше восьми студентов на дипломные работы, и как шутят сами студенты - в лаборатории хроматографии жесткий кастинг. И это оправдано, поскольку молодые сегодня прагматичны и уже на первом курсе знают, куда нужно идти за знаниями, которые впоследствии гарантируют высокую зарплату.

В лаборатории сейчас работают четыре доктора наук и еще две докторских диссертации на выходе, состав докторов наук постоянно молодеет.

Основное направление наших научных исследований-создание новых сепарационных материалов для ионной хроматографии. Мы продолжаем этим интенсивно заниматься и для хроматографии гидрофильных взаимодействий, активно контактируем с сотрудниками факультета наук о материалах. Сегодня наша задача - заменить силикагель на оксид титана, что вот уже двадцать с лишним лет пытаются сделать во всем мире.

Оборудованием лаборатория обеспечена, но оно, к сожалению, стареет, и очень быстро. Большая проблема еще и в том, что руководство университета выделяет деньги на приобретение приборов, а бремя их содержания ложится на факультет. При этом хороший прибор - хроматограф стоит около 35 млн руб. В свое время выручала компания Agilent, с которой у нас была партнерская лаборатория: мы бесплатно эксплуатировали их оборудование, а они его сами ремонтировали и заменяли. К сожалению, эти времена закончились, из партнерских лабораторий Agilent оставил в Европе только три.

Посмотрим, что будет дальше, но факультет не в состоянии выдерживать финансовую нагрузку, которая необходима для поддержания приборов. В качестве решения проблемы есть две идеи, первая - организация Центра коллективного пользования при активном финансовом участии ректората. Эта объединенная структура декларирована министерством, объявлен конкурс. Второй вариант - поиск богатых партнеров, в том числе в нефтегазовой отрасли, и сейчас мы этим занимаемся. Сотрудничаем с геологами в части ранней разведки нефтяных месторождений, над этим активно работают норвежцы, а мы стараемся сейчас реализовать импортозамещение. Необходимо найти специальные сорберы, которые при анализе шурфа с глубины один метр способны дать ответ-есть там нефть или нет, и даже с определенной долей вероятности указать

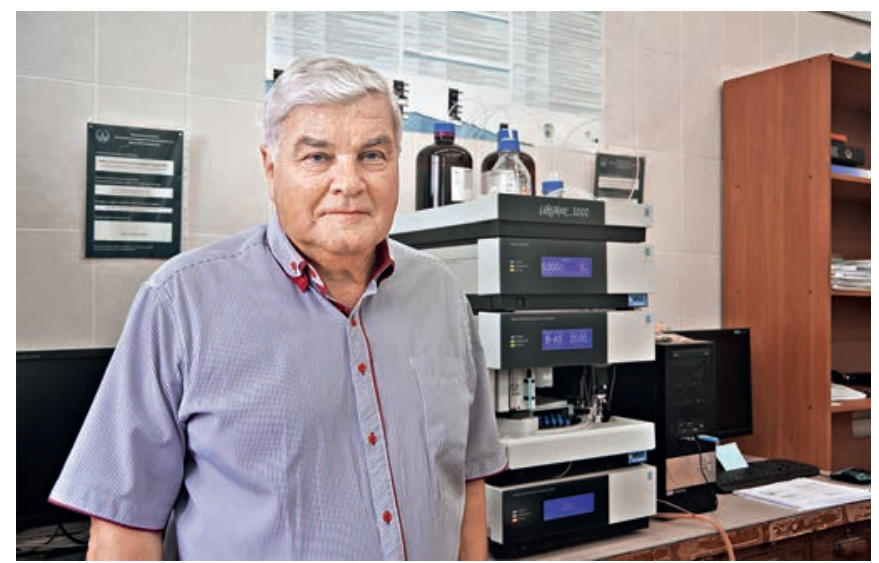

глубину, на которой она находится. Совместными усилиями факультета при нашем участии этот проект продвигается. Есть надежда, что вскоре появятся результаты, с которыми можно будет обратиться к "Газпром нефти» с предложением создать совместный центр. Пока речь идет о сорберах и хромато-массспектрометрии, но эффективны могут быть еще и гамма-съемка, и рентгенофлуоресцентный анализ. Идея состоит в создании совместного R\&D-центра с ПАО «Газпром нефть».

Еще мы ведем работу по созданию новыханионообменников для ионной хроматографии, вскоре по этой теме планируется защита докторской диссертации. Исследования ведет наша всемирно признанная группа, которая публикуется в очень высокорейтинговых журналах. Есть собственные сорбенты, но, к сожалению, при внедрении новых разработок возникают определенные проблемы. К сожалению, закон 228-Ф3 о малых предприятиях при научных организациях не слишком облегчает ситуацию. Сложности возникнут у нас и при попытке коммерциализации упомянутого проекта по новым сорберам для нефтегазовой отрасли. Но мы не отчаиваемся и с надеждой смотрим в будущее.

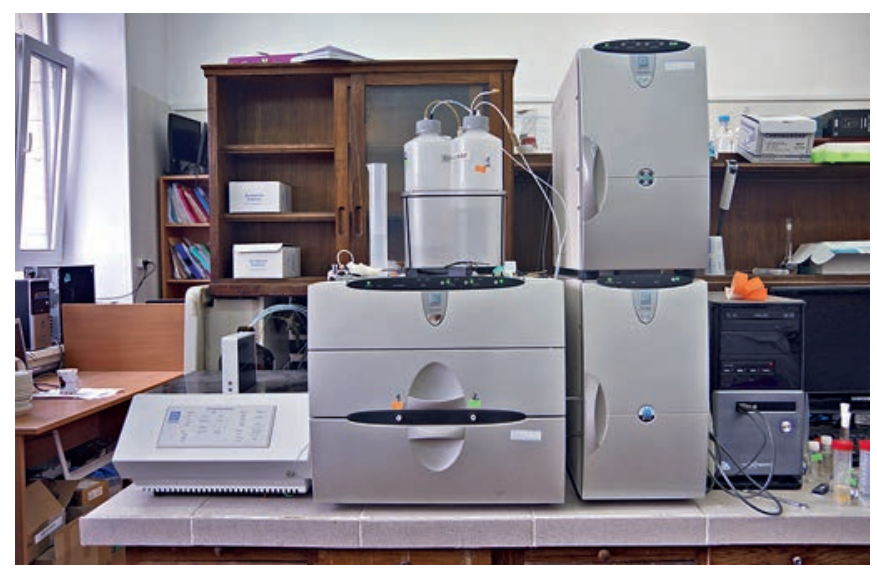

Ионный хроматограф Dionex ICS-3000 


\section{ЛАБОРАТОРИЯ МАСС-СПЕКТРОМЕТРИИ}

Рассказывает доктор химических наук, ведущий научный сотрудник, и. о. заведующего лабораторией Игорь Александрович Родин

Тематика наших исследований - применение аналитической хромато-масс-спектрометрии для исследования соединений, обладающих физиологической активностью. Основное направление работы - развитие методологии анализа и расширение ее возможностей для решения самых разнообразных задач, связанных прежде всего с физиологически активными сильнодействующими соединениями лекарственными препаратами, экотоксикантами и ядами. Нас интересуют вопросы пробоподготовки, совершенствование технологии жидкостной хроматографии, в том числе препаративной, и хромато-масс-спектрометрия в двух основных современных вариантах - газовой и высокоэффективной жидкостной.

Научная группа, которую я возглавляю, разрабатывает несколько тем. У нас два больших, магистральных направления. Первое из них связано с исследованием и развитием методов качественного и количественного анализа для определения сильнодействующих компонентов растительного происхождения. Его можно охарактеризовать как аналитическую фитохимию: прежде всего это исследование соединений, входящих в состав растений, которые давно зарекомендовали себя в качестве лекарственных, но в силу сложного состава не до конца понятен механизм их действия. Это мостик между традиционными и до сих пор популярными, особенно в Азии - Корее, Китае и Японии, фармакологиями, и западной фармацией, которая нацелена на некоторое определенное вещество. Задача состоит в том, чтобы современными методами исследовать компоненты, входящие в состав растительного сырья: выделить и полностью охарактеризовать. То есть необходимо изучить и понять механизмы действия веществ растительного происхождения и построить картину, характерную для стандартных лекарственных средств. Эта тематика развивается с 2011 года, по ней много сделано, инициатором является государство. В 2017 году мы с Андреем Николаевичем Ставрианиди были награждены премией Москвы для молодых ученых. Работа была высоко оценена и продолжается дальше.

Вторая магистральная тема разрабатывается с 2005 года и ее можно охарактеризовать как аналитическую токсикологию - развитие методологии определения и идентификации экзогенных сильнодействующих соединений и их метаболитов в живых организмах. Работа в этом направлении началась со взаимодействия с профессором Игорем Владимировичем Рыбальченко, крупнейшим в нашей стране специалистом по аналитическому сопровождению вопросов, связанных с химическим разоружением, ликвидацией химического оружия, выполнением конвенции о запрещении химического оружия. Наша совместная

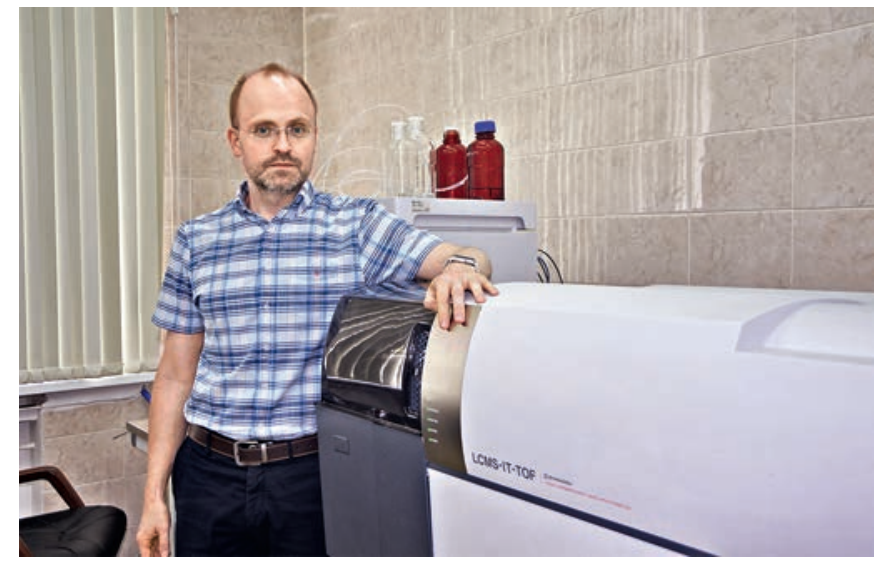

деятельность, которая за эти годы выросла и расширилась, состоит в развитии хромато-масс-спектрометрических методов для определения соединений, возникающих при воздействии отравляющих веществ на живой организм, так называемых биомаркеров отравления. По этому научному направлению защищено несколько диссертаций, в том числе моя докторская. Эта работа была отмечена крупной наградой - премией Митрополита Макария за 2018 год, присуждаемой совместно РПЦ и РАН. Возрожденная 20 лет назад премия ведет свою историю с 19 века. В 2018 году она впервые присуждалась по естественным и точным наукам с формулировкой "за работы, обладающие большой государственной и социальной значимостью".

Мы работаем и по другим проектам, связанным с исследованием лекарственных средств, активно взаимодействуем с компаниями и другими институтами, выполняем самые разнообразные измерения и исследования аналитического характера с использованием описанного комплекса методов. Круг наших партнеров очень широк.

Сейчас обсуждается проект по использованию хромато-масс-спектрометрии высокого разрешения в криминалистическом анализе, нашим соисполнителем будет недавно созданный институт криминалистики Следственного комитета. Сотрудничаем с другими кафедрами нашего факультета - радиохимии, органической химии, медицинской химии и тонкого органического синтеза, химии нефти и органического катализа, химии природных соединений. Для них мы проводим необходимые масс-спектрометрические и хроматографические измерения, а также участвуем как полноценные коллабораторы в их крупных научных проектах. Взаимодействуем и с другими факультетами, в частности заключили договор на разработку проектов спецификаций фармсубстанций для коллег с факультета фундаментальной медицины МГУ. 
Международные программы развиваются не очень активно, что связано с высокой востребованностью внутри страны, однако мы планируем в ближайшее время начать реализацию масштабного проекта совместно с группой Олега Майбороды из Университета Лейдена (Нидерланды) по развитию методологии хромато-массспектрометрического анализа в области метаболомики.

Хочу рассказать еще о некоторых перспективных планах, которые мы стремимся реализовать. Это, прежде всего, работа в области метаболомного анализа в сочетании с методами машинного обучения и анализа Big Data. Цель - поиск метаболических маркеров, которые могут быть полезны для ранней диагностики онкопатологий. Есть уже несколько партнеров и хороший задел в плане компетенций, сформирован коллектив, отработана методологическая часть. Занимаемся сбором образцов биоматериалов от пациентов с подтвержденным диагнозом и тех, у кого сходные патологии, но онкология исключена. Надеюсь, что к концу года, когда накопим необходимый объем образцов, работа перейдет активную стадию. Мы плотно взаимодействуем с Первым Московским государственным медицинским университетом им. И. М. Сеченова, с 1-й Градской больницей и другими крупными медицинскими организациями. В качестве основного рабочего инструмента по этому проекту мы задействовали ВЭЖХMC-ВP-систему SHIMADZU IT-TOF, которую с недавних пор эксплуатируем совместно с нашими партнерами - группой компаний "Интераналит», генеральным дистрибьютором японской приборостроительной корпорации Shimadzu. Прибор обладает большими возможностями для реализации наших планов.

\section{ЛАБОРАТОРИЯ ЭЛЕКТРОХИМИЧЕСКИХ МЕТОДОВ}

Рассказывает заведующий лабораторией д. х. н., профессор Аркадий Аркадьевич Карякин

Ведущее направление работы лаборатории - биосенсоры. В этой области мы - одни из мировых лидеров, что подтверждается публикациями в ведущих журналах. Более 10 лет я являюсь соредактором (Associate Editor) международных журналов - сначала это был журнал Electroanalysis издательства Wiley-VCH, а затем Electrochemistry Communications, выпускаемый издательством Elsevier.

Что касается практики, то мы достигли такого уровня, когда крупные фирмы начинают интересоваться нашими разработками. В частности, совместно с группой компаний "Юнимед" сейчас проходит сертификацию первый клинический анализатор глюкозы и лактата на отечественных картриджах, или биосенсорах. Самая крупная российская компания на рынке персональных глюкометров, "Элта", предложила нам заняться созданием глюкозных тестов

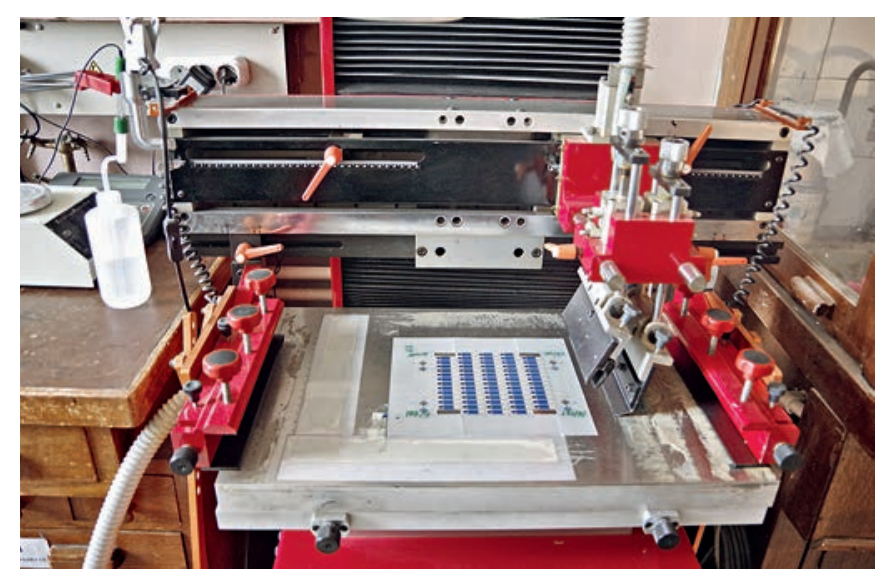

Полуавтоматический универсальный станок для трафаретной nечатu SCF-300 нового поколения. Наши датчики будут обладать более

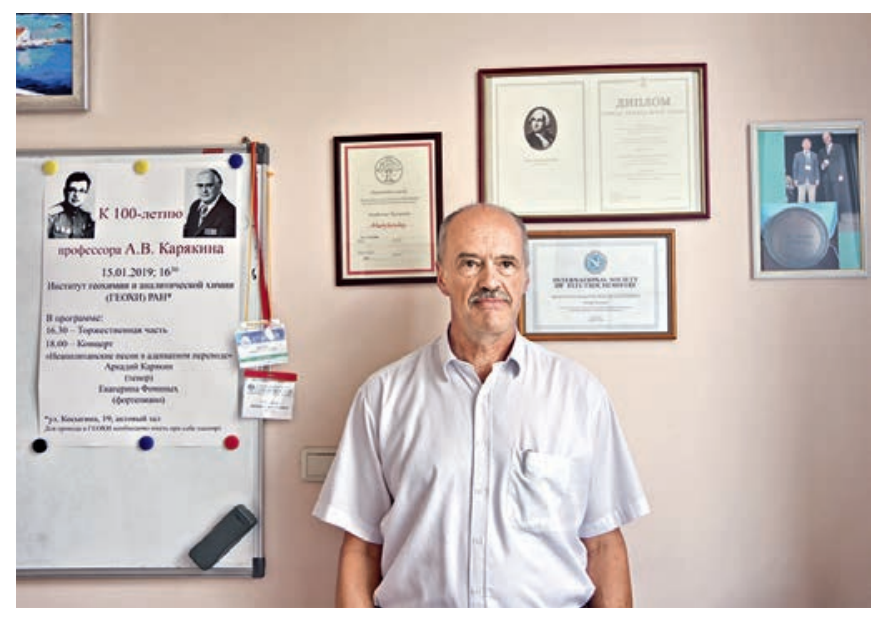

высокой селективностью и воспроизводимостью результатов. Сегодня во всем мире датчики одноразовые, обычно их калибруют, отбирая от большой произведенной партии малую часть, по которой судят об аналитических характеристиках всей партии. При этом возникает проблема их хранения у потребителя, условия которого могут оказать впоследствии влияние на качество их работы.

Поэтому возник интерес к переходу на кулонометрические датчики, которые свободны от перечисленных недостатков. В мире они появились примерно 20 лет назад, но до сих пор в нашу страну даже не импортируются.

Кроме того, мы сейчас занимаемся неинвазивными методами анализа без отбора крови и нарушения кожных покровов. У нас есть лабораторные образцы и прототипы таких приборов, которые готовы к внедрению на производстве. 
Свои разработки мы конечно патентуем, но сегодня гораздо эффективнее декларировать свой приоритет посредством публикаций в ведущих международных журналах. Так, например, в этом году у меня вышла 21-я статья в самом престижном аналитическом журнале - Analytical Chemistry, который издается с 1929 года American Chemical Society. Уровень публикаций в этом журнале - гарантия того, что наш приоритет никто не сможет оспорить и получить патент на аналогичную разработку. Что же касается самого патента, то только его поддержка стоит сегодня около 100 тыс. долл. в год. Кстати, за рубежом патентованием занимаются государственные организации.

Что касается применения, то ранее мы пытались наладить отношения с представителями пищевой промышленности, но из этой затеи ничего не вышло, поскольку большинство предприятий не очень заинтересовано в подобном сотрудничестве.

В Японии, например, когда появились первые биосенсоры, на государственном уровне озаботились контролем качества пищевых продуктов. В частности, разработан специальный нож для контроля качества рыбы, который при ее разрезании сигнализирует о присутствии продуктов биоразложения. Без такой проверки продукция не допускается к продаже.

Сегодня мы пытаемся внедрить свои разработки в медицину. Участие таких гигантов бизнеса как "Элта" и "Юнимед" позволяет надеяться, что фундаментальные достижения в области биосенсоров займут достойное место в новых медицинских приборах и послужат улучшению здоровья и качества жизни наших сограждан.

\section{ЛАБОРАТОРИЯ БИОАНАЛИТИЧЕСКИХ МЕТОДОВ И ОПТИЧЕСКИХ СЕНСОРНЫХ СИСТЕМ}

Рассказывает заместитель заведующего кафедрой аналитической химии по научной работе

д. х. н., доцент Ирина Анатольевна Веселова

Основные направления научных исследований лаборатории связаны с развитием биоаналитических методов и созданием оптических сенсорных систем для мониторинга и контроля качества окружающей среды, технологических объектов, фармацевтических препаратов и растительного сырья, биомедицинской диагностики. Большинство клинических лабораторий и экологических служб использует серийное оборудование, которое не всегда может справляться с решением ряда задач химического анализа на современном уровне. Ключевая цель наших фундаментальных исследований состоит в создании умных и простых сенсорных элементов (чипов), которые можно использовать в обычных спектрофотометрах, спектрофлуориметрах, рамановских спектрометрах - для распознавания и определения биологически активных веществ, экотоксикантов, маркеров качества

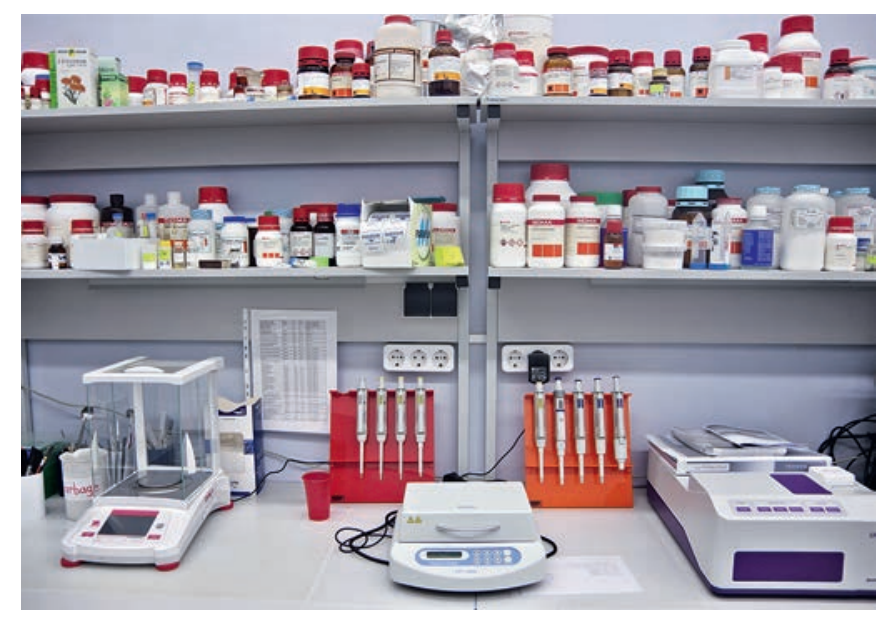

Оборудование иаборатории различных технологических объектов, окружающей среды, продуктов питания без предварительной (или минимальной) подготовки проб к анализу.

Достигается этот результат за счет того, что практически весь процесс проходит на сенсорном элементе, сигнал от которого получает прибор. Такой подход помогает без дополнитель-

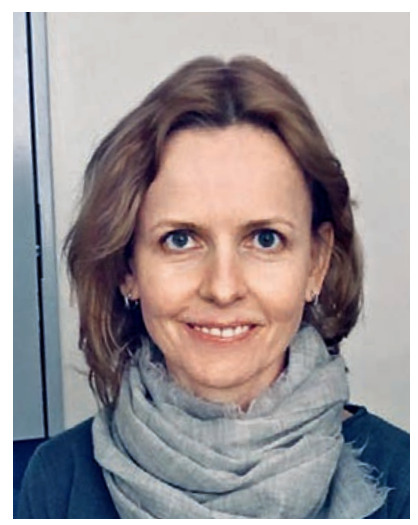

ных затрат и привлечения высококвалифицированного персонала проводить в клинических или экологических

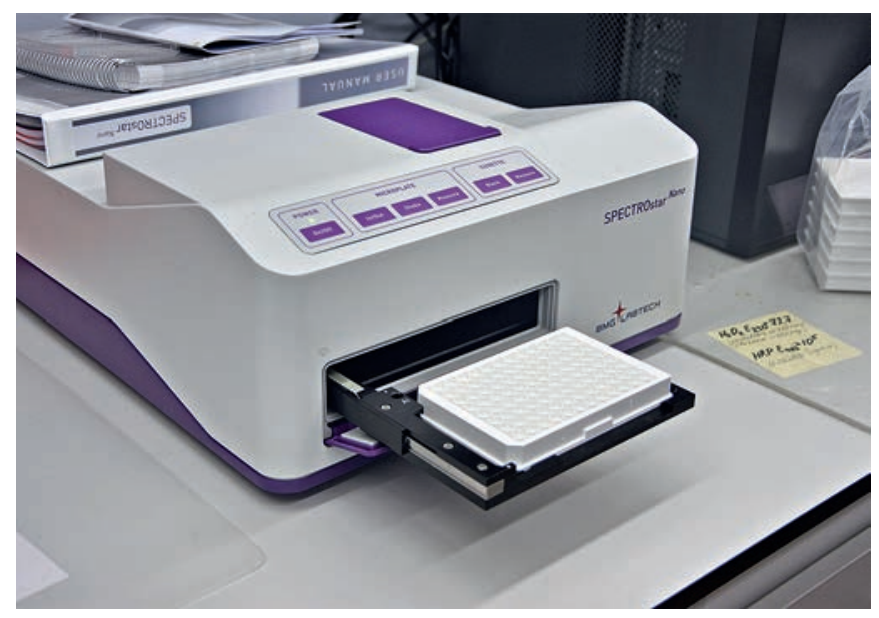

Планшетный спектрофотометр SPECTROstar NANO 


\section{Sigma-Aldrich.}

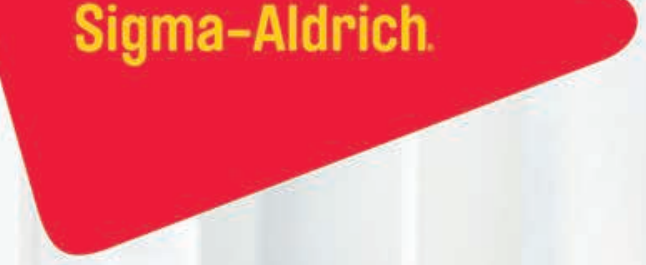

"...инновационные материалы начинаются с инновационной химии."

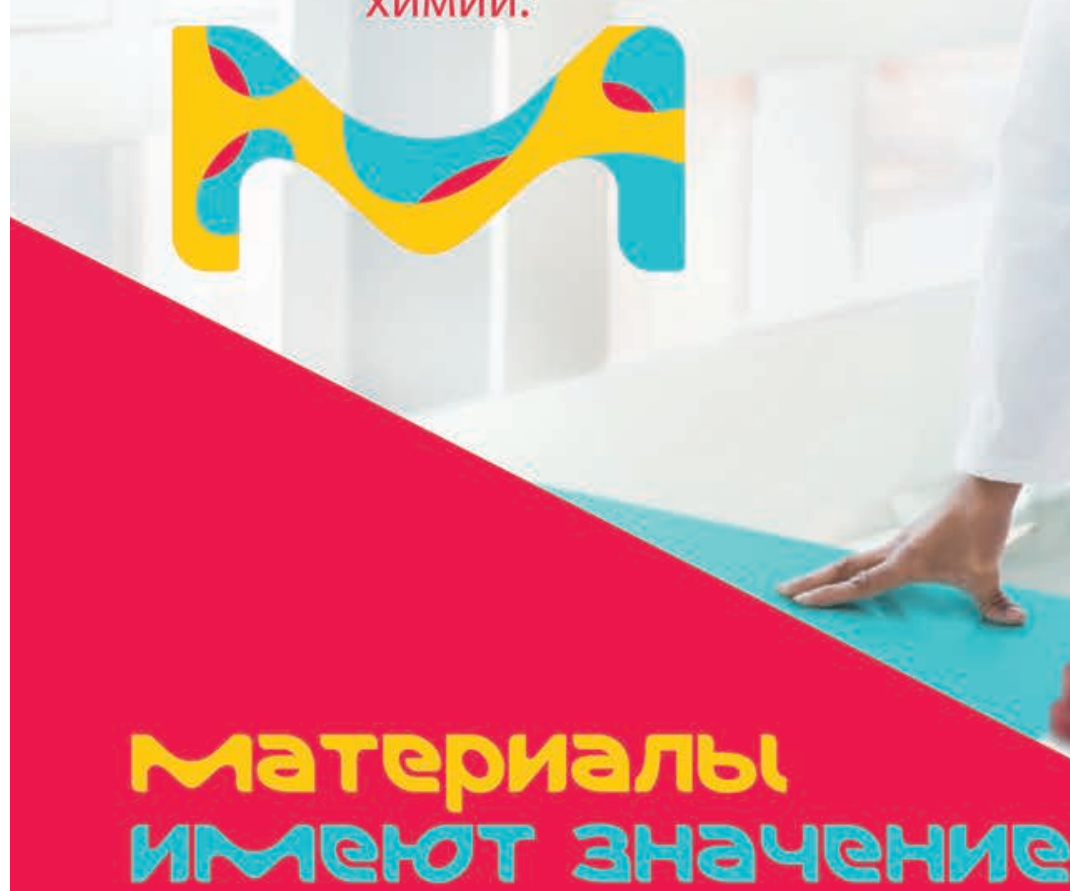

Синтез материалов

- Соли, металлы и оксиды

- Материалы для напыления/осаждения

- Сверхвысокочистые материалы

Наноматериалы

- Неорганические наноматериалы

- Углеродные наноматериалы

- Квантовые точки

- Мезопористые материалы

3D-печать

- Биочернила

- Проводящие чернила

Доставка лекарств

- Биоразлагаемые полимеры

- Функционализированные ПЭГи

- Природные полимеры
Органическая и печатная электроника

- OLED и PLED материалы

- Opганические фотоэлектрические материалы

- Световые и оптические материалы

- Самособирающиеся материалы

\section{Полимеры}

- Полимеры

- Мономеры

- Инициаторы полимеризации

Узнайте больше на нашем сайте:

www.sigma-aldrich.com/materials-science.html 
лабораториях исследования, сравнимые по своей информативности с масс-спектрометрическими или хроматографическими методами. На сегодняшний момент мы можем в ряде случаев определять одновременно до восьми биологически активных веществ в одной пробе, что очень важно, например, для клинической диагностики или при решении экологических или технологических задач.

Создание таких сенсорных устройств - результат интенсивной работы всей научной группы. Мы используем как классические распознающие биологические системы с участием ферментов, антител, нуклеиновых кислот, так и дополнительно работаем с сенсорными поверхностями, задавая им особые свойства, чтобы они одновременно распознавали требуемые соединения с нужной чувствительностью и при этом усиливали оптический сигнал, получаемый с подложки. На это не способны ни биологическая молекула, ни сам прибор, но модифицированная поверхность усиливает флуоресцентный сигнал или сигнал комбинационного рассеяния за счет различных плазмонных эффектов во много раз.

Исследования проводятся в сотрудничестве с различными медицинскими учреждениями, российскими и зарубежными биохимическими исследовательскими центрами, нефтяными компаниями, то есть потенциальными потребителями наших научных разработок.

Сегодня достигнуты значительные результаты в области создания сенсорных систем для мультиплексного определения маркеров нейромедиаторного обмена (катехоламинов, их предшественников и метаболитов), окислительного стресса (прежде всего пероксидов различной природы), широкого круга антиоксидантов (например, флавоноидов), лекарственных препаратов, экологических и техногенных маркеров (полиароматических углеводородов, серосодержащих соединений, фенолов различного строения, альдегидов) в различных по природе объектах: от клеточных структур до нефтяных продуктов.

Желаем колиективу кафедры успехов на ниве отечественного образования, дапьнейших свершений в научной работе и реапизации их на практике!

С сотрудниками кафедры беседовапи О. А. Лаврентьева и В. В. Родченкова

\section{ХИМИКИ СОЗДАЛИ И ПОКАЗАЛИ НОВУЮ ФОРМУ УГЛЕРОДА}

Ученые создали новую форму углерода, названную циклоуглеродом, и подтвердили это фотографиями, полученными с помощью атомносилового микроскопа. Связи между атомами имеют попеременно разную длину, формируя кольцо, состоящее из 18 атомов и девяти сторон. Циклоуглерод соединяет и дру гие модификации углерода, включая алмаз, графит, тонкие листы, называемые графеном, крошечные сферы, известные как бакиболлы (фуллерены), и миниатюрные цилиндры, называемые углеродными нанотрубками. Химики знали о существовании возможности создания кольцевых молекул углерода, однако до сих пор не могли предсказать их свойств.

Катарина Кайзер и ее коллеги (IBM Research, Цюрих) начали работать с молекулами оксида циклоуглерода, состоящего из атомов углерода, расположенных в петле с дополнительными группами оксида углерода, присоединенными к атомам. Исследователям удалось избавиться от постороннего монооксида углерода с помощью атомносилового микроскопа, приложив к молекуле напряжение.

В результате было получено чистое кольцо углерода. Циклоуглерод легко реагирует с другими веществами поэтому для его выделения новую молекулу углерода создали на инертной поверхности поваренной соли Исследования показали, что атомы углерода удерживаются вместе путем чередования одинарных и тройных связей. Это открытие помогло ученым провести сложные компьютерные вычисления для прогнозирования структур неизвестных молекул.

Предыдущая работа над новыми формами углерода знаменовалась открытием в 1980-х годах фуллеренов и Нобелевской премией. Аналогично, за открытие графена

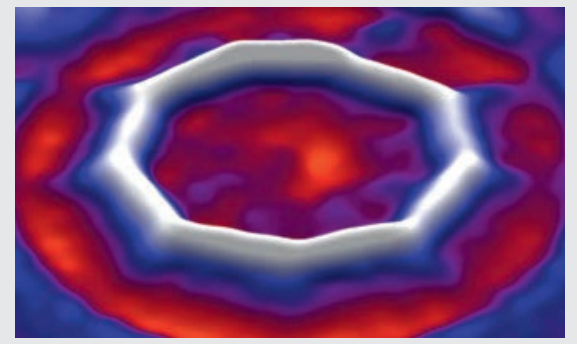

в 2004 году также была получена Нобелевская премия, что породило масштабные исследования его потенциальных применений в электронике.

Недостаток полученного результата состоит в том, что циклоуглерод нестабилен, его пока не удается собрать в емкости для дальнейшего изучения. Пока неясно, насколько масштабным будет применение новой молекулы и какие перспективы открываются после ее открытия и синтеза.

Источник: sciencenews.org 
Приглашаем Вас и Bauy организаuиlo принять участие B мероприятиях Зимнего симпозиума по хемометрuke WSC-12 B kачестße гостей, участнико $\mathrm{u}$ cnoнсоров!

\title{
$12^{\text {th }}$ Winter Symposium on Chemometrics
}

\author{
Russia, Saratov, February 24-28, 2020
}

24-28 феевраля 2020 гола в Саратове на базе комплекса «Волжские Аали» состоится 12-ый межАунароАный Зимний симпозиум по хемометрике - Winter Symposium on Chemometrics, WSC-12, организатором которого является Российское хемометрическое общество и Институт химии Саратовского государственного национального исследовательского университета имени Н.Г. Чернышевского. Симпозиум посвящен рассмотрению широкого круга вопросов, связанных с современными методами и областями применения многомерного анализа Аанных.

Участниками симпозиума являются веАущие специалисты по разработке и применению хемометрических метоАов в различных областях науки и техники, преАставители производственных преАприятий и бизнеса. ТраАиционно WSC поААерживает участие молодых ученых, проявляющих интерес к анализу Аанных.

В рамках симпозиума предполагаются пленарные и секционные заседания и неорормальные вечерние встречи.

http://wsc.chemometrics.ru/wsc12/

\section{Школа анализа многомерных Аанных}

Перел началом Зимнего симпозиума по хемометрике, 22-23 февраля 2020 гола, на базе Института химии Саратовского национального исслеАовательского государственного университета имени Н.Г. Чернышевского, пройлет 2-дневная школа «Ввеление в анализ многомерных Аанныхи.

Рабочий язык школы - русский.

Программа включает лекции и семинары, цель которых - познакомить слушателей с основами хемометрики. Аия практических занятий буАут использоваться Microsoft Excel и специально разработанная наАстройка Chemometric Add-In. Занятия будут провоАить опытные препоАаватели, сотруАникИ РАН.

ПредсеАатель оргкомитета WSC-12 - А.X.Н. Наталия Анатольевна Бурмистрова Саратовский государственный университет, e-mail: naburmistrova@mail.ru тел. +7-927-109-79-44 